Research

\title{
THE EFFECT OF INSURANCE PREMIUMS, CLAIMS, UNDERWRITING RESULTS, ON PROFITABILITY WITH A RISK-BASED MINIMUM CAPITAL RATIO (RBMC) AS AN INTERVENING VARIABLE IN GENERAL INSURANCE COMPANIES
}

\author{
${ }^{1}{ }^{\star}$ Richad Alamsyah dan ${ }^{2)}$ Ahmad Lutfi \\ ${ }^{1.2)}$ Kesatuan Business Informatics Institute Bogor \\ 1)alamsyahrichard@gmail.com ,
}

Received: May 08, 2021; Accepted: June 20, 2021; Published: June 30, 2021

${ }^{*}$ Corresponding author

To cite this article: Alamsyah, R \& Lutfi, A (2021). The effect of insurance premiums, claims, underwriting results, on profitability with a risk-based minimum capital ratio (RBMC) as an intervening variable in general insurance companies. The Accounting Journal of BINANIAGA. 6 (1), 61-80. doi: $10.33062 / a j b . v 6 i 1.434$

\begin{abstract}
This research aims to examine the effect of profitability (ROA) with insurance premiums, claims and underwriting results as independent variables and the RBMC ratio as an intervening variable in insurance companies in Indonesia for the 2016-2018 period.

The selection of the research sample was carried out using a purposive sampling method and based on predetermined criteria, a sample of 72 companies was obtained. The data in this study are secondary data. Data processing is done by statistical analysis techniques, namely multiple regression analysis and the Sobel test method in intervening testing.

The results of this study indicate that (1) Insurance premiums have no effect on the RBMC ratio, (2) Insurance Claims have a negative effect on the $R B M C$ ratio, (3) Underwriting results have a positive effect on the RBMC ratio, (4) Insurance premiums have a positive effect on profitability (ROA). , (5) Insurance Claims have a negative effect on profitability (ROA), (6) Underwriting results have a positive effect on profitability (ROA), (7) RBMC ratio has a positive effect on profitability (ROA), (8) Insurance Premiums have no indirect effect on profitability (ROA) through the RBMC Ratio, (9) Insurance Claims indirectly have no effect on profitability (ROA) through the RBMC Ratio, (10) Underwriting Results indirectly have no effect on profitability (ROA) through the RBMC Ratio
\end{abstract}

Keywords: Underwriting Result, Insurance Claims, Insurance Premium, Profitability, RBMC Ratio.

\section{INTRODUCTION}

\section{Background}

The insurance industry has its own uniqueness compared to other industries. According to Prawoto in Fadlin (2013), there are several characteristics that distinguish insurance companies from other non-bank institutions, namely the underwriting function and the claim

Richard Alamsyah and Ahmad Lutfi. The effect of insurance premiums, claims, underwriting results, on profitability with a risk-based minimum capital ratio (RBMC) as an intervening variable in general insurance companies 
handling function. As a risk collector company, the underwriting function plays an important role in the performance of insurance companies and guarantees the company to create profits. Meanwhile, company profits play an important role in ensuring the existence and sustainability of the company. Therefore, it is very important for industrial actors to know the factors that cause the rise and fall of profits.

The company's ability to create profits can be influenced by several factors. According to Reschiwati (2018), several factors that can affect the profit of insurance companies include insurance premiums, insurance claims and underwriting results.

Reschiwati (2018) in her research, insurance premiums have no effect on insurance profits. However, this is not the case with Pratiwi's research (2017) which concludes that insurance premiums have an influence on insurance profits. This is in line with the research of Utami and Marwansyah (2017) where insurance premiums have a positive effect on increasing company profits.

The next factor is insurance claims, according to Winarso (2014) insurance claims are compensation from the insured against the insurer in the event of a loss of goods or objects insured in the insurance contract. Based on research from Reschiwati (2018), claims have a negative effect on company profits. This is in line with the research of Utami and Marwansyah (2017) which states that insurance claims have a negative effect on company profits. However, this is different from the research conducted by Winarso (2014) where in his research claims have a positive effect on profits.

Next is the underwriting result factor which is the profit or loss of the main insurance activity obtained from the difference between underwriting income and underwriting expenses. According to Reschiwati (2018), underwriting results have a positive effect on profits, but the results of this study are different from Pratiwi (2017) who concludes that underwriting results have no effect on company profits.

In carrying out its business activities, insurance collects funds from the public in the form of premiums making this industry included in the regulated industry category or industrial category supervised by the government. One of the mandates in the regulation is to require all insurance industry players to maintain a Risk-Based Minimum Capital ratio (RBMC). RBMC ratio according to POJK No. 71/POJK. 05/2016 is the amount of funds needed to anticipate the risk of loss that may arise as a result of deviations in asset and liability management. The minimum RBMC ratio limit that must be met by industry players is $120 \%$.

Therefore, it is important for industrial players to know things that can affect the increase and decrease in the RBMC ratio. According to research by Alamsyah (2017), Tarigan (2015) and Rahmawati (2016) there are several factors that influence the RBMC ratio including insurance premiums, insurance claims, underwriting results which can be described as follows.

Research conducted by Rahmawati (2016) concluded that insurance premiums have a positive and significant effect on the increase in the decrease in the RBMC ratio. However, the results of this study are different from the results of Alamsyah's (2017) research where the results of the study conclude that insurance premiums have no effect on the RBMC ratio.

Based on insurance financial reports listed on the Indonesia Stock Exchange (IDX), the comparison of the RBMC ratio with insurance claims from 2013-2017 shows that the increase in the number of claims is not affected by the increase or decrease in the RBMC ratio. The results of this study are not in line with the results of Alamsyah's research (2017) which states that insurance claims have a significant effect on the RBMC ratio. Alamsyah's

Richard Alamsyah and Ahmad Lutfi. The effect of insurance premiums, claims, underwriting results, on profitability with a risk-based minimum capital ratio (RBMC) as an intervening variable in general 
research is in line with research conducted by Tarigan (2015) and Rahmawati (2017) which states that insurance claims have a significant effect on the RBMC ratio.

Underwriting results are the result of the company's risk management. The better the risk management of a company, the better the underwriting results of an insurance company which can have an impact on the fulfillment of the RBMC ratio. This is in accordance with Tarigan's research (2015) which concludes that underwriting has an influence on the RBMC Ratio. However, based on insurance financial reports listed on the IDX, the comparison of the RBMC ratio with the underwriting results in 2013-2017 shows that the increase in underwriting results does not affect the increase or decrease in the RBMC ratio.

Regarding some gaps between the reality experienced and also the results of previous research studies that have been described by the researcher in the previous paragraphs, the researcher is interested in conducting this research. This research refers to the research of Reschiwati (2018) and Pratiwi (2017) which examines the effect of insurance premiums , insurance claims and underwriting results on profitability. The difference from this study compared to previous research is that the sampling is based on the number of insurance companies listed on the Indonesia Stock Exchange, while this study takes a wider sample, namely all general insurances in Indonesia which are under the supervision of the Financial Services Authority. The next difference is that the researcher tries to add the RBMC ratio as an intervening variable. This is based on research by Ahmad \& Prasetyo (2018) which states that there is a relationship between the RBMC ratio to profitability and the research of Tarigan (2015) and Alamsyah (2017) which concludes that there is a relationship between insurance premiums, insurance claims and underwriting results on the RBMC ratio.

Based on this background, this research takes the title: Effect of Insurance Premiums, Insurance Claims and Underwriting Results on Profitability with Risk-Based Minimum Capital Ratio (RBMC) as an Intervening Variable.

\section{Formulation of the Problem}

The formulation of the problem in this study is as follows:

1. Does insurance premium affect the RBMC ratio?

2. Does insurance claim affect the RBMC ratio?

3. Does the underwriting result affect the RBMC ratio?

4. Does insurance premium affect profitability?

5. Do insurance claims affect profitability?

6. Does the underwriting result affect profitability?

7. Does the RBMC ratio affect profitability?

8. Does insurance premium affect profitability through the RBMC ratio as an intervening variable?

9. Do insurance claims affect profitability through the RBMC ratio as an intervening variable?

10. Does the underwriting result affect profitability through the RBMC ratio as an intervening variable?

Richard Alamsyah and Ahmad Lutfi. The effect of insurance premiums, claims, underwriting results, on profitability with a risk-based minimum capital ratio (RBMC) as an intervening variable in general insurance companies 
The Accounting Journal of BINANIAGA Vol. 06, No. 01, June 2021

p-ISSN: 2527-4309, e-ISSN: 2580-1481

$5^{\text {th }}$ Accreditation Rating: January 14, 2019 - January 13, 2024

\section{REVIEW OF LITERATURE}

\section{Insurance Premium}

Premium according to Law No. 20 of 2014 is an amount of money determined by the Insurance Company or reinsurance company and approved by the Policy Holder to be paid based on the Insurance agreement or reinsurance agreement, or an amount of money determined based on the provisions of the legislation that underlies the compulsory insurance program to obtain benefits.

Meanwhile, according to Budisantoso in Hasnah (2019), insurance premiums are a certain amount of funds that must be paid by the insured party to the insurer for the risk transferred in accordance with the insurance agreement.

\section{Underwriting Result}

According to Salim (2018:111) underwriting is a process of selecting a small risk to get the maximum profit. Underwriting results are the difference between underwriting income and underwriting expenses. Underwriting income is derived from gross premium income less reinsurance premiums and increase/decrease in premium reserves.

\section{Insurance Claim}

Law No. 40 of 2014 states that a claim is a claim for compensation from the insured against the insurer (insurance) in the event of an accident on the insured item/object. Winarso (2014) defines a claim as compensation for the insured for the risks guaranteed in the insurance contract.

\section{Risk-Based Minimum Capital}

According to the Financial Services Authority regulation No. 71 / POJK.05/2016 RBMC is the amount of funds needed to anticipate the risk of loss that may arise as a result of deviations in asset and liability management. In an effort to maintain stability and guarantee the health level of the insurance industry, the Government in this case the Financial Services Authority sets a minimum RBMC limit that must be achieved by every insurance company, which is $120 \%$.

\section{Profitability}

According to Subramanyam and Wild (2010:109) profit is a description of the results of business operational activities within a certain period of time expressed in financial terms. Meanwhile, Fikri in Winarso (2014) explains that profit or loss is income minus all expenses or costs that have been incurred in a certain period. Based on the above understanding, it can be concluded that profit is the excess of income over costs in return for producing goods and services for one period. accounting.

\section{Conceptual Framework}

Insurance in doing its business by collecting public funds, it is necessary for government intervention in an effort to ensure every insurance company is in a healthy condition. The health of an insurance company is measured in the RBMC calculation.

There are several factors that affect profitability, including insurance premiums, insurance claims, underwriting results, and the RBMC ratio which is the moderating variable. From the explanation above, it can be formed a framework as in Figure 1:

Richard Alamsyah and Ahmad Lutfi. The effect of insurance premiums, claims, underwriting results, on profitability with a risk-based minimum capital ratio (RBMC) as an intervening variable in general insurance companies 


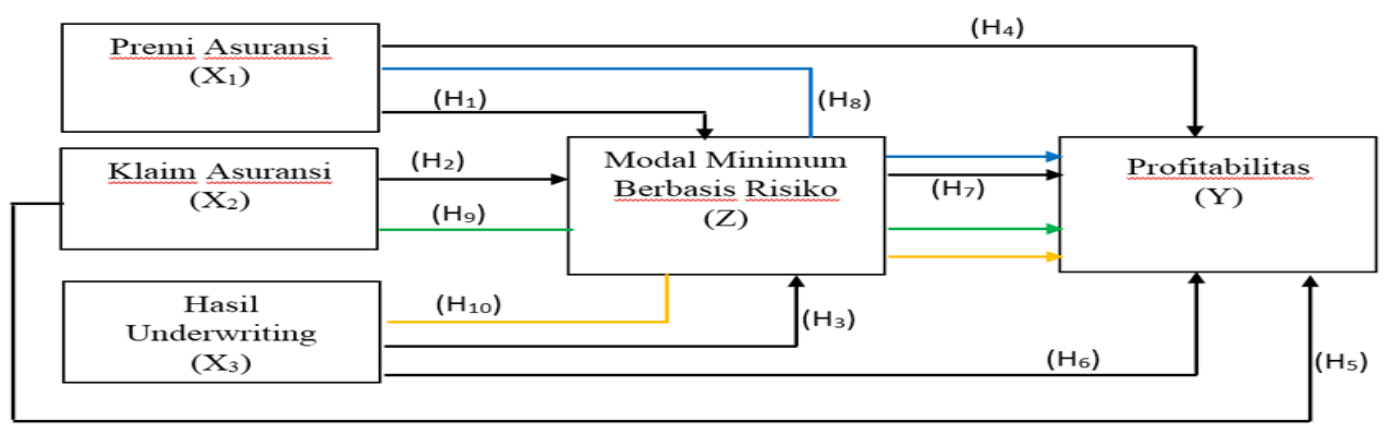

Sources: Tarigan (2015), Alamsyah (2017), Pratiwi (2017), Rahmawati (2017) Reschiwati (2018), Leviany (2017), Hasnah (2019), Aniseh (2019) and developed for this research (2019)

Figure 1 Framework

\section{Hypothesis Development}

In accordance with the framework of thinking and the underlying theoretical background, the hypothesis of this research can be formulated as follows:

\section{Effect of Insurance Premium with RBMC Ratio}

In calculating the RBMC ratio, the premium reserve on the acquisition of insurance premiums is one of the elements used in the calculation, especially in the calculation of insurance risk. So that the acquisition of insurance premiums will have an impact on increasing or decreasing the RBMC ratio.In a research conducted by Rahmawati (2017) stated that insurance premiums have a positive effect on the risk-based minimum capital ratio as well as research conducted by Nur (2018) which states that the acquisition of insurance premiums has a positive effect on the RBMC ratio. Based on the empirical evidence of previous research that has been described above, the first hypothesis is proposed as follows:

\section{$\mathrm{H}_{1}$ : "Insurance Premiums have a Positive effect on the RBMC Ratio."}

\section{Effect of Claims with RBMC Ratio}

The amount of claims reserves will affect the amount of liabilities and is able to enlarge the liability side of the balance sheet which will affect the calculation of the size of the solvency level, namely the allowed wealth assessment. Based on Alamsyah's research (2017) where the results of his research show that insurance claims have a negative effect on the riskbased minimum capital ratio (RBMC), this is supported by Susilowati's research (2017) which concludes that insurance claims have a negative effect on the risk-based minimum capital ratio (RBMC). Based on the empirical evidence of previous research that has been described above, the second hypothesis is proposed as follows:

\section{$\mathrm{H}_{2}$ : "Insurance Claims have a Negative effect on the RBMC Ratio."}

Richard Alamsyah and Ahmad Lutfi. The effect of insurance premiums, claims, underwriting results, on profitability with a risk-based minimum capital ratio (RBMC) as an intervening variable in general insurance companies 


\section{Effect of Underwriting Result with RBMC Ratio}

The underwriting result is the difference between the underwriting incomes and the underwriting expenses. The higher the underwriting results, the better the risk management of a company which has an impact on increasing the company's RBMC ratio. This is in line with research conducted by Tarigan (2015), Aniseh (2019 and Susilowati (2017) where underwriting results have a positive influence on the RBMC ratio. To examine the relationship between underwriting results and the RBMC ratio, this study formulates the following hypothesis:

\section{$\mathrm{H}_{3}$ : "Underwriting Resultshave a Positive effect on the RBMC Ratio."}

\section{Effect of Insurance Premium on Profitability}

Receipt of insurance premiums obtained by insurance companies is the amount of income from the sale of insurance policies which is generally measured in a certain period. Ahmad and Prasetyo (2018) state that companies that have large premium receipts will also experience an increase in profits. Several studies have been conducted on the relationship between insurance premiums and profitability. Hasnah (2019) and Wulandari (2019) in their research conclude that insurance premiums have a positive effect on profitability. This is in line with the research of Utami and Marwansyah (2017) and the research of Ahmad \& Prasetyo (218) which concluded that insurance premiums have a positive and significant relationship to company profitability. Based on the previous research that has been described above, the fourth hypothesis is proposed as follows:

\section{$\mathrm{H}_{4}$ : "Insurance Premiums Have a Positive Effect on Profitability."}

\section{Effect of Insurance Claim on Profitability}

When the company has a high claim burden, it can reduce the company's revenue which has an impact on the company's profit decline. Several studies were conducted to determine the relationship of insurance claims to the company's profitability. Utami and Marwansyah (2017) in their research mention that insurance claims have a negative relationship to company profitability. This is in line with Reschiwati's research (2018) which found that insurance claims have a significant relationship to profitability. Based on the previous research that has been described above, the fifth hypothesis is proposed as follows:

\section{$\mathrm{H}_{5}$ : "Insurance Claims Have a Negative Effect on Profitability."}

\section{Effect of Underwriting Result on Profitability}

The underwriting result is the result of a risk assessment obtained from the difference between underwriting income and the company's underwriting expense. This underwriting result is one of the variables forming net income. The higher the underwriting result will increase the amount of profit at the Reschiwati insurance company (2018). Ahmad \& Prasetyo (2018) conclude that underwriting results have a positive influence on profitability. Likewise, research conducted by Reschiwati (2018) and Susulowati (2017) which states that underwriting results have a positive relationship to profitability. Based on the previous research described above, the sixth hypothesis is proposed as follows:

\section{$\mathrm{H}_{6}$ : "Underwriting Results have a Positive Effect on Profitability."}

Richard Alamsyah and Ahmad Lutfi. The effect of insurance premiums, claims, underwriting results, on profitability with a risk-based minimum capital ratio (RBMC) as an intervening variable in general 


\section{Effect of RBMC Ratio on Profitability}

A large RBMC ratio indicates the company is able to manage its assets and liabilities well. Leviany (2014) said the company's ability to generate profits will depend on the company's ability to manage its assets and liabilities. Thus it can be concluded that with good corporate health management, it is expected to increase the company's profitability. Several studies have been conducted regarding the relationship between the RBMC ratio and the company's profitability. Ahmad \& Prasetyo (2018) in their research found the RBMC ratio has a positive relationship to profitability. A similar study was conducted by Pratiwi (2017) and found that the RBMC ratio has a positive effect on profitability, based on the previous research described above, the seventh hypothesis is proposed as follows:

\section{$H_{7}$ : "RBMC Ratio have a Positive Effect on Profitability."}

\section{Effect of RBMC Ratio as Intervening Reinsurance Premium Relationship with} Profitability

Insurance premiums are the main income of insurance companies. With a premium, the company is expected to be able to increase profit. Utami and Marwansyah (2017) in their research conclude that insurance premiums have a positive influence on company profitability. The same thing was expressed by Ahmad \& Prasetyo (2018) in their research which concluded that insurance premiums have a positive effect on profitability. In addition, the premium has a positive effect on the RBMC ratio. This is supported by research by Rahmawati (2017) which concludes that insurance premiums have a positive influence on the RBMC ratio. Based on the description above, the eighth hypothesis is proposed as follows:

\section{$\mathrm{H}_{8}$ : "RBMC Ratio Mediates the Effect of Insurance Premiums on Profitability."}

\section{Effect of Insurance Claims on Profitability with RBMC Ratio as Intervening}

Insurance claim is one element of profit deduction. Reschiwati (2018) concludes that insurance claims have a negative relationship to profitability. This is in line with the research conducted by Utami and Marwansyah (2017) in their research which concludes that insurance claims have a negative effect on company profitability. In addition, insurance claims have a direct relationship to the RBMC ratio. Several studies have been conducted regarding the relationship between insurance claims and the RBMC ratio, including Alamsyah (2017) concluding that insurance claims have a positive effect on the RBMC ratio. This is in line with Tarigan's (2015) research which concludes that insurance claims have a positive effect on the RBMC ratio. Based on the description above, the ninth hypothesis is proposed as follows:

\section{$\mathrm{H}_{9}$ "RBMC Ratio Mediates the Effect of Insurance Claims on Profitability."}

\section{Effect of Underwriting Result on Profitability with RBMC Ratio as Intervening}

Underwriting results are the difference between underwriting income and underwriting expenses. The higher the underwriting result, the better the risk selection process for the company which will have an impact on increasing the company's profit. Reschiwati (2018) concludes that underwriting results have a positive influence on company profits. The same thing was also expressed by Prasetyo (2018) in his research which concluded that underwriting results had a positive influence on profitability. In addition, underwriting results have an influence on the RBMC ratio. Tarigan (2015) in his research concludes that

Richard Alamsyah and Ahmad Lutfi. The effect of insurance premiums, claims, underwriting results, on profitability with a risk-based minimum capital ratio (RBMC) as an intervening variable in general insurance companies 
The Accounting Journal of BINANIAGA Vol. 06, No. 01, June 2021

p-ISSN: 2527-4309, e-ISSN: 2580-1481

$5^{\text {th }}$ Accreditation Rating: January 14, 2019 - January 13, 2024

underwriting results have a positive influence on the RBMC ratio. Based on the description above, the tenth hypothesis is proposed as follows:

$\mathrm{H}_{10}$ "RBMC Ratio Mediates the Effect of Underwriting Results on Profitability."

\section{RESEARCH METHODOLOGY}

\section{Measurement of research variables}

In general, the measurement of variables is presented in the following:

Table 1

Variable Operations

\begin{tabular}{|c|c|c|c|}
\hline $\begin{array}{l}\text { Variable } \\
\text { Type }\end{array}$ & Proxy & Variable Measurement & $\begin{array}{l}\text { Measurement } \\
\text { Scale }\end{array}$ \\
\hline \multirow[t]{3}{*}{$\begin{array}{l}\text { Independent } \\
\text { Variable }\end{array}$} & $\begin{array}{l}\text { Insurance premium } \\
\text { Reschiwati (2018) } \\
\text { Utami and Marwansyah } \\
\text { (2017) }\end{array}$ & $\begin{array}{l}\text { Natural Lognatural of Insurance } \\
\text { Premium }\end{array}$ & Ratio \\
\hline & $\begin{array}{l}\text { Insurance Claim } \\
\text { Tarigan (2015) } \\
\text { Alamsyah (2017) }\end{array}$ & $\begin{array}{l}\text { Natural Logarithm of Insurance } \\
\text { Claims }\end{array}$ & Ratio \\
\hline & $\begin{array}{l}\text { Underwriting Result } \\
\text { Reschiwati (2018) } \\
\text { Ahmad \& Prasetyo (2018) }\end{array}$ & $\begin{array}{l}\text { Underwriting Income - } \\
\text { Underwriting Results }\end{array}$ & Ratio \\
\hline $\begin{array}{l}\text { Intervening } \\
\text { Variables }\end{array}$ & $\begin{array}{l}\text { Risk-Based Minimum } \\
\text { Capital Ratio (RBMC) } \\
\text { Reg. of OJK No. } \\
\text { 71/POJK.05/2016 }\end{array}$ & $\frac{\text { Total Solvency Level }}{\text { Minimum Solvency Level Limit }}$ & Ratio \\
\hline $\begin{array}{l}\text { Dependent } \\
\text { Variable }\end{array}$ & $\begin{array}{l}\text { Profitability } \\
\text { Ahmad \& Prasetyo (2018) } \\
\text { Hasnah (2019) }\end{array}$ & $\frac{\text { Profit Before Tax }}{\text { Total Assets }}$ & Ratio \\
\hline
\end{tabular}

\section{Population and Sample}

The population in this research are, all companies, that run insurance businesses operating in Indonesia for the period 2016-2018. In this study the sample was taken based on certain criteria (purposive sampling). This technique was chosen to obtain a representative sample in accordance with predetermined criteria.

The criteria for the companies that will be sampled in this research are as follows:

1. General Insurance Company registered and under the supervision of the Financial Services Authority from 2016-2018;

2. Companies that consistently publish audited financial reports with the financial year ending on December 31 during the study period, namely from 2016-2018; and

3. Insurance Companies that have a risk-based minimum capital ratio above $120 \%$ in accordance with the provisions of the Financial Services Authority regulations.

Richard Alamsyah and Ahmad Lutfi. The effect of insurance premiums, claims, underwriting results, on profitability with a risk-based minimum capital ratio (RBMC) as an intervening variable in general insurance companies 


\section{Data Collecting Method}

This research uses secondary which is data that has been previously processed in the form of data published in financial statements. The data source is taken directly from secondary data from the 2016-2018 annual financial statements published by public companies sourced from newspapers.

\section{Data Analysis Method}

To test the hypothesis of this research using the regression method and also path analysis (Path Analysis). However, the descriptive statistical test, normality test, and classical assumption test first before testing the hypothesis.

\section{RESULTS AND DISCUSSION}

\section{Descriptive Statistical Analysis}

Descriptive analysis aims to determine the description of the research data. This analysis is presented in the form of minimum, maximum, mean, and standard deviation values. Here are the descriptive results of each variable which can be seen in table 2.

Table 2

Descriptive Statistics Results

\begin{tabular}{crrrrr}
\hline Variables & N & Minimum & Maximum & Mean & Std. Deviation \\
\hline Insurance Premium & 216 & $11,300.00$ & 6636484.00 & 787197.59 & 1103534.28 \\
\hline Insurance Claim & 216 & $4,117.00$ & 3397693.00 & 399177.98 & 576410.01 \\
\hline Underwriting Result & 216 & $-4,7638.00$ & 1196619.00 & 177800.11 & 212054.64 \\
\hline RBMC & 216 & 136.00 & 1748.00 & 346.00 & 267.24 \\
\hline
\end{tabular}

\section{Normality Test}

In this research using normality testing using the Kolmogoov-Smirnov test with a level of $a=$ 0.05 . Based on table 3 , it can be seen that the results of the normality test using the Kolmogoov-Smirnov test show that the variable has an asymp value. sig (2-tailed) $>0.05$.

Table 3

\section{Normality Test Results}

\begin{tabular}{clll}
\hline Model & \multicolumn{1}{c}{ Variables } & $\begin{array}{c}\text { Asymp. Sig. } \\
\text { (2-tailed) }\end{array}$ & Result \\
\hline Model 1 & Insurance Premium (PA) & 0.095 & $\begin{array}{l}\text { Normally } \\
\text { Distributed }\end{array}$ \\
& Insurance Claim (KA) & & \\
& Underwriting Result (HU) & & \\
\hline
\end{tabular}

Richard Alamsyah and Ahmad Lutfi. The effect of insurance premiums, claims, underwriting results, on profitability with a risk-based minimum capital ratio (RBMC) as an intervening variable in general insurance companies 
The Accounting Journal of BINANIAGA Vol. 06, No. 01, June 2021

p-ISSN: 2527-4309, e-ISSN: 2580-1481

$5^{\text {th }}$ Accreditation Rating: January 14, 2019 - January 13, 2024

\begin{tabular}{clll}
\hline Model & \multicolumn{1}{c}{ Variables } & $\begin{array}{c}\text { Asymp. Sig. } \\
\text { (2-tailed) }\end{array}$ & Result \\
\hline Model 2 & Insurance Premium (PA) & 0.200 & $\begin{array}{l}\text { Normally } \\
\text { Distributed }\end{array}$ \\
& Insurance Claim (KA) & & \\
& Underwriting Result (HU) & & \\
\hline
\end{tabular}

Dependent Model 1: RBMC

Dependent Model 2: Profitability

From the results of the normality test, it can be seen that model 1 has an Asymp value. Sig. (2-tailed) is 0.095 so the significance value is above 0.05 which indicates the data is normally distributed. Likewise for model 2 where the Asymp value. Sig. (2-tailed) of 0.200 which is greater than 0.05 in other words the data is normally distributed.

\section{Multicollinearity Test}

The multicollinearity test aims to determine whether there is a high relationship between the independent variables. There is no multicollinearity problem if the Tolerance value is above 0.1 and the VIF is below 10 .

Table 4

Multicollinearity Test Results

\begin{tabular}{lllll}
\hline $\begin{array}{c}\text { Regression Model } \\
\text { no.- }\end{array}$ & \multicolumn{1}{c}{ Variables } & Tolerance & VIF & Remarks \\
\hline Regression Model 1 & Insurance Premium & 0.132 & 7.554 & Non Multicollinearity \\
\cline { 2 - 5 } & \begin{tabular}{l}
. Insurance Claim \\
\cline { 2 - 5 }
\end{tabular} & 0,144 & 6.953 & Non Multicollinearity \\
\hline $\begin{array}{l}\text { Underwriting } \\
\text { Results }\end{array}$ & 0.423 & 2.363 & Non Multicollinearity \\
\hline Regression Model2 & \begin{tabular}{l} 
Insurance Premium \\
\cline { 2 - 5 }
\end{tabular} & 0.127 & 7.845 & Non Multicollinearity \\
\cline { 2 - 5 } & $\begin{array}{l}\text { Insurance Claim } \\
\text { Underwriting }\end{array}$ & 0.139 & 7.204 & Non Multicollinearity \\
\hline & Results & 0.349 & 2.864 & Non Multicollinearity \\
\cline { 2 - 5 } & RBMC & 0.690 & 1.448 & Non Multicollinearity \\
\hline
\end{tabular}

Dependent Model 1: RBMC

Dependent Model 2: Profitability

The results above show the tolerance value of each independent variable is above 0.1 and VIF is below 10 so it can be said that there is no multicollinearity, meaning that there is no high relationship between the independent variables.

Richard Alamsyah and Ahmad Lutfi. The effect of insurance premiums, claims, underwriting results, on profitability with a risk-based minimum capital ratio (RBMC) as an intervening variable in general insurance companies 


\section{Heteroscedasticity Test}

Heteroscedasticity test aims to test whether in the regression model there is an inequality of variance from the residual of one observation to another observation. In this study, the heteroscedasticity test used the glejser test. The criterion is that there is no heteroscedasticity problem if the significance probability is above the 0.05 significance level.

Table 5

Heteroscedasticity Test Results

\begin{tabular}{llll}
\hline $\begin{array}{l}\text { Regression } \\
\text { Model no.- }\end{array}$ & \multicolumn{1}{c}{ Variables } & Significance & Remarks \\
\hline $\begin{array}{l}\text { Regression } \\
\text { Model 1 }\end{array}$ & Insurance Premium & 0.347 & Non Heteroscedasticity \\
\cline { 2 - 4 } & Insurance Claim. & 0.899 & Non Heteroscedasticity \\
\cline { 2 - 4 } & Underwriting Results & 0.756 & Non Heteroscedasticity \\
\hline $\begin{array}{l}\text { Regression } \\
\text { Model 2 }\end{array}$ & Insurance Premium & 0.638 & Non Heteroscedasticity \\
\cline { 2 - 4 } & Insurance Claim & 0.908 & Non Heteroscedasticity \\
\cline { 2 - 4 } & Underwriting Results & 0.431 & Non Heteroscedasticity \\
\cline { 2 - 4 } & RBMC & 0.980 & Non Heteroscedasticity \\
\hline
\end{tabular}

Heteroscedasticity test results obtained that each independent variable in the regression model has a significance value above 0.05 so it can be said that the regression model does not contain symptoms of heteroscedasticity.

\section{Autocorrelation Test}

There is no autocorrelation if the Durbin Watson value is between du and 4-du. In regression model 1, the value of du with 216 data and the number of variables 3 is 1.807 so that 4 -du becomes 4-1.807 = 2.193 (using the $n 220$ approach). And Durbin Watson's score of 2.158 is already between 1.807 and 2.193. In regression model 2, the value of du with 216 data and the number of variables 4 is 1.816 so that 4-du becomes $4-1.816=2.184$ (using the $n 220$ approach). And the Durbin Watson score of 1.874 is already between 1.816 and 2.184. The results of the above test obtained that the two regression models do not have autocorrelation problems.

Table 6

Autocorrelation Test Results

\begin{tabular}{lcccl}
\hline \multicolumn{1}{c}{ Regression Model } & du & 4-du & DW & Remarks \\
\hline $\mathrm{X} 1 ; \mathrm{X} 2 ; \mathrm{X} 3 \rightarrow \mathrm{Z}$ & 1.807 & 2.193 & 2.158 & Non Autocorrelation \\
\hline
\end{tabular}

Richard Alamsyah and Ahmad Lutfi. The effect of insurance premiums, claims, underwriting results, on profitability with a risk-based minimum capital ratio (RBMC) as an intervening variable in general insurance companies 
The Accounting Journal of BINANIAGA Vol. 06, No. 01, June 2021

p-ISSN: 2527-4309, e-ISSN: 2580-1481

$5^{\text {th }}$ Accreditation Rating: January 14, 2019 - January 13, 2024

\begin{tabular}{ccccl}
\hline Regression Model & du & 4-du & DW & Remarks \\
\hline $\mathrm{X} 1 ; \mathrm{X} 2 ; \mathrm{X} 3 ; \mathrm{Z} \rightarrow \mathrm{Y}$ & 1.816 & 2.184 & 1.874 & Non Autocorrelation \\
\hline
\end{tabular}

\section{Coefficient of Determination Test (Adj. $\mathbf{R}^{2}$ )}

Based on table 7, in model 1, the Adjusted $R$ value is 0.3 and the coefficient of determination obtained is $0.300 \times 100 \%=30 \%$, which means that the variation in the dependent variable, namely RBMC, can be explained by variations in the independent variable, namely insurance premiums, insurance claims and underwriting results are $30 \%$. While in model 2, the Adjusted $R$ value is 0.178 and the coefficient of determination obtained is $0.178 \times 100 \%=17.8 \%$, which means the magnitude of the variation of the dependent variable.

Table 7

Coefficient of Determination Test Results (Adj. $\mathbf{R}^{2}$ )

\begin{tabular}{lccc}
\hline Model & R & R Square & Adjusted R Square \\
\hline Model 1 & $0.556^{\mathrm{a}}$ & 0.310 & 0.300 \\
\hline Model 2 & $0.440^{\mathrm{a}}$ & 0.193 & 0.178 \\
\hline
\end{tabular}

Dependent Model 1: RBMC

Dependent Model 2: Profitability

\section{Simultaneous Test (F)}

The criteria for acceptance or rejection are if the significance value of $F<0.05$ then the hypothesis is accepted, and if the significance value of $F>0.05$ then the hypothesis is rejected. To find out whether the variables of insurance premiums, insurance claims and underwriting results, the RBMC ratio have a simultaneous effect on profitability, the $F$ test is carried out, the results of which can be seen in table 8 as follows:

Table 8

F Test Result

\begin{tabular}{cccc}
\hline Model & & $\mathbf{F}$ & Sig. \\
Model 1 & Regression & 31.675 & 0.000 \\
\hline Model 2 & Regression & 12.644 & 0.000 \\
\hline
\end{tabular}

Dependent Model 1: RBMC

Dependent Model 2: Profitability

Based on table 8 , it can be seen that there is a joint influence between independent variables if the calculated $F$ value is greater than $F$ table and the significance is less than 0.05 . In model 1 the calculated $F$ value is 31.675 and the significance is 0.000 so that the calculated $F$ value is greater than $F$ table and the significance is less than 0.05 , it can be concluded that

Richard Alamsyah and Ahmad Lutfi. The effect of insurance premiums, claims, underwriting results, on profitability with a risk-based minimum capital ratio (RBMC) as an intervening variable in general insurance companies 
there is a simultaneous effect of insurance premiums, insurance claims, and underwriting results on the minimum capital ratio based on RBMC risk. While in model 2 the calculated $F$ value is 12.644 and a significance of 0.000 so that the calculated $F$ value is greater than the $\mathrm{F}$ table and the significance is less than 0.05 , it can be concluded that there is a simultaneous effect of insurance premiums, insurance claims, and underwriting results, and the ratio $\mathrm{RBMC}$ on profitability.

\section{Partial Test (t)}

Simple regression and multiple regression aim to test the relationship of influence, test the effect of one variable on another variable. The results of multiple regression testing for the research model using the SPSS 19 program can be seen in Table 9 as follows.

Table 9

Multiple Regression Test Results

\begin{tabular}{lllcccl}
\hline Model & Variables & $\begin{array}{l}\text { Initial } \\
\text { Hypothesis }\end{array}$ & Unstandardized B & T count & $\begin{array}{l}\text { Sig. } \\
\text { (1- } \\
\text { tail) }\end{array}$ & Decision \\
\hline Model 1 & $\begin{array}{l}\text { Insurance } \\
\text { Premium }\end{array}$ & $\begin{array}{l}\text { Positive } \\
\text { Effect }\end{array}$ & -0.202 & -2.855 & 0.002 & $\begin{array}{l}\mathrm{H}_{1} \\
\text { Rejected }\end{array}$ \\
\cline { 2 - 7 } & $\begin{array}{l}\text { Insurance } \\
\text { Claim. }\end{array}$ & $\begin{array}{l}\text { Negative } \\
\text { Effect }\end{array}$ & -0.175 & -2.768 & 0.003 & $\mathrm{H}_{2}$ \\
& $\begin{array}{l}\text { Underwriting } \\
\text { Results }\end{array}$ & $\begin{array}{l}\text { Positive } \\
\text { Effect }\end{array}$ & 0.163 & 6.705 & 0.000 & $\begin{array}{l}\mathrm{H}_{3} \\
\text { Accepted }\end{array}$ \\
\hline Model 2 & $\begin{array}{l}\text { Insurance } \\
\text { Premium }\end{array}$ & $\begin{array}{l}\text { Positive } \\
\text { Effect }\end{array}$ & 2.239 & 3.723 & 0.000 & $\begin{array}{l}\mathrm{H}_{4} \\
\text { Accepted }\end{array}$ \\
\cline { 2 - 7 } & $\begin{array}{l}\text { Insurance } \\
\text { Claim }\end{array}$ & $\begin{array}{l}\text { Negative } \\
\text { Effect }\end{array}$ & -2.177 & -4.054 & 0.000 & $\begin{array}{l}\mathrm{H}_{5} \\
\text { Accepted }\end{array}$ \\
\cline { 2 - 7 } & $\begin{array}{l}\text { Underwriting } \\
\text { Results }\end{array}$ & $\begin{array}{l}\text { Positive } \\
\text { Effect }\end{array}$ & 0.711 & 3.178 & 0.001 & $\begin{array}{l}\mathrm{H}_{6} \\
\text { Accepted }\end{array}$ \\
\cline { 2 - 7 } & $\begin{array}{l}\text { Positive } \\
\text { RBMC }\end{array}$ & 1.049 & 1.828 & 0.035 & $\begin{array}{l}\mathrm{H}_{7} \\
\text { Accepted }\end{array}$ \\
\hline
\end{tabular}

Dependent Model 1: RBMC

Dependent Model 2: Profitability

So that the regression model can be obtained as follows:

Model $1: Z=10.05-0.202 X_{1}-0.175 X_{2}+0.163 X_{3}$

Model $2: Y=-7.188+2.239 X_{1}-2.177 X_{2}+0.711 X_{3}+1.049 Z$

Richard Alamsyah and Ahmad Lutfi. The effect of insurance premiums, claims, underwriting results, on profitability with a risk-based minimum capital ratio (RBMC) as an intervening variable in general insurance companies 


\section{Effect of Insurance Premium on RBMC Ratio}

The insurance premium variable has a t value of -2.855 and a significance of 0.002 . the significance value is less than 0.05 so that there is a partially significant effect of the insurance premium variable on the RBMC ratio. The regression coefficient value $-0,202$ indicates a negative effect. Based on the t-test, it is concluded that the $\mathrm{H}_{1}$ hypothesis is rejected, where the results show that insurance premiums have no effect on the RBMC ratio.

\section{Effect of Insurance Claim on RBMC Ratio}

The insurance claim variable has a t value of -2.768 and a significance of 0.003 so that the significance value is less than 0.05 , so there is a partially significant effect of the variable of insurance claims on the RBMC ratio. The regression coefficient value of -0.175 indicates a negative effect. Based on the t-test, insurance claims have a negative effect on the RBMC ratio, thus it is concluded that $\mathrm{H}_{2}$ is accepted.

\section{Effect of Underwriting Result on RBMC Ratio}

The underwriting result variable has a t-count value of 6.705 and a significance of 0.000 so that the significance value is less than 0.05 , so there is a partially significant effect of the variable from the underwriting result on the RBMC ratio. The regression coefficient value of 0.163 indicates a positive influence. The results of the t-test of underwriting results have a positive effect on the RBMC ratio, thus it is concluded that $\mathrm{H}_{3}$ is accepted.

\section{Effect of Insurance Premium on Profitability}

The insurance premium variable has a t value of 3.723 and a significance of 0.000 so that the significance value is less than 0.05 , so there is a partially significant effect of the variable of insurance premiums on profitability. The regression coefficient value of 2.239 indicates a positive influence. Based on the initial hypothesis $\mathrm{H} 4$ insurance premiums have a positive effect on profitability. Likewise, the results of the t-test conclude that insurance premiums have a positive effect on profitability, thus it is concluded that $\mathrm{H}_{4}$ is accepted.

\section{Effect of Insurance Claim on Profitability}

Insurance claims have a t value of -4.054 and a significance of 0.000 so that the significance value is less than 0.05 , so there is a partially significant effect of the variable of insurance claims on profitability. The regression coefficient value -2.177 indicates a negative influence. The results of the $t$ test conclude that insurance claims have a negative effect on profitability, thus it is concluded that $\mathrm{H}_{5}$ is accepted.

\section{Effect of Underwriting Result on Profitability}

The underwriting result variable has a t-count value of 3.178 and a significance of 0.001 so that the significance value is less than 0.05 , so there is a partially significant effect of the variable from the underwriting result on profitability. The regression coefficient value of 0.711 indicates a positive influence. The results of the t-test concluded that the insurance underwriting results had a positive effect on profitability, thus it was concluded that $\mathrm{H}_{6}$ was accepted.

\section{Effect of Risk-Based Minimum Capital Ratio (RBMC) on Profitability}

The RBMC ratio has a t-count value of 1.828 and a significance of 0.035 so that the significance value is less than 0.05 , thus there is a partial effect between the variables of the RBMC ratio on profitability. Based on the initial hypothesis $\mathrm{H}_{8}$, the $\mathrm{RBMC}$ ratio has a positive effect on profitability. Based on the results of the significance test, it can be concluded that Hypothesis $\mathrm{H}_{7}$ is accepted.

Richard Alamsyah and Ahmad Lutfi. The effect of insurance premiums, claims, underwriting results, on profitability with a risk-based minimum capital ratio (RBMC) as an intervening variable in general 


\section{Sobel Test}

Sobel test results can be seen in table 10

Table 10

Sobel Test Results

\begin{tabular}{|c|c|c|c|c|c|c|}
\hline \multirow{3}{*}{ Independent Variables } & \multicolumn{6}{|c|}{ Indirect Test } \\
\hline & \multicolumn{2}{|c|}{$X ® Z$} & \multicolumn{2}{|c|}{$\mathrm{Z} \circledast \mathrm{Y}$} & \multicolumn{2}{|c|}{ Sobel® Test } \\
\hline & $\mathrm{B}$ & Std Error & B & Std Error & $\mathrm{T}$ & Sig \\
\hline Insurance Premium $\left(X_{1}\right)$ & -0.448 & 0.071 & \multirow{3}{*}{0.136} & \multirow{3}{*}{0.574} & -0.236 & 0.813 \\
\hline Insurance Claim $\left(\mathrm{X}_{2}\right)$ & -0.416 & 0.063 & & & -0.237 & 0.812 \\
\hline Underwriting Results $\left(\mathrm{X}_{3}\right)$ & 0.588 & 0.024 & & & -0.237 & 0.813 \\
\hline
\end{tabular}

Sobel Test Results:

Indirect Effect of Insurance Premium on Profitability through the RBMC Ratio.

The results of the Sobel Test show that the sig value of the $X 1 \rightarrow Z \rightarrow Y$ path is 0.813 or greater than 0.05 . These results indicate that insurance premiums do not have an indirect effect on profitability through the RBMC ratio, thus $\mathrm{H}_{8}$ is rejected.

\section{Indirect Effect of Insurance Claim on Profitability through the RBMC Ratio.}

The results of the Sobel Test show that the sig value of the $X 2 \rightarrow Z \rightarrow Y$ path is 0.812 or greater than 0.05 . These results indicate that insurance claims do not have an indirect effect on profitability through the $\mathrm{RBMC}$ ratio, thus $\mathrm{H}_{9}$ is rejected.

\section{Indirect Effect of Underwriting Result on Profitability through the RBMC Ratio.}

The results of the Sobel Test show that the sig value of the $X 3 \rightarrow Z \rightarrow Y$ path is 0.813 or greater than 0.05 . These results indicate that underwriting results do not have an indirect effect on profitability through the $\mathrm{RBMC}$ ratio, thus $\mathrm{H}_{10}$ is rejected.

\section{Discussion of research results}

\section{Effect of Insurance Premium on RBMC Ratio}

The results of the study show that insurance premiums have no effect on the RBMC ratio. These results are in line with Alamsyah's research (2017) concluding that there is no influence between insurance premiums on the RBMC ratio. These results are in line with Putu's research (2016) which concludes that insurance premiums have no effect on the RBMC ratio.

\section{Effect of Insurance Claim on RBMC Ratio}

Richard Alamsyah and Ahmad Lutfi. The effect of insurance premiums, claims, underwriting results, on profitability with a risk-based minimum capital ratio (RBMC) as an intervening variable in general insurance companies 
The results show that insurance claims have a negative effect on the RBMC ratio. This condition is in line with Alamsyah's research (2017) which concludes that claims have a negative effect on the RBMC ratio. This is in line with Susilowati's research (2017) which concludes that insurance claims have a negative effect on the RBMC ratio.

\section{Effect of Underwriting Result on RBMC Ratio}

The results showed that underwriting results had a positive relationship to the RBMC ratio. The results of this study support research conducted by Tarigan (2015) and Aniseh (2019) which concludes that underwriting results have a positive influence on the RBMC ratio.

\section{Effect of Insurance Premium on Profitability}

Insurance premiums are one of the main sources of income in the insurance industry. The results showed that insurance premiums have a positive relationship to profitability. This condition supports the research of Ahmad (2018) and Utami and Marwansyah (2017) where the increase in insurance premiums is able to increase the level of company profitability.

\section{Effect of Insurance Claim on Profitability}

The results showed that insurance claims had a negative effect on profitability. This condition is supported by the research of Pratiwi (2018) and Reschiwati (2018) where the results of their research conclude that insurance claims have a negative effect on profitability.

\section{Effect of Underwriting Result on Profitability}

Underwriting results are an indicator that reflects the good or bad of the risk sorting process. This research is in line with research by Ahmad (2018) which concludes that underwriting results have a positive influence on company profitability. This is in line with research by Reschiwati (2018) and Ahmad and Prasetyo (2018) which conclude that underwriting results have a positive effect on profitability.

\section{Effect of Risk-Based Minimum Capital Ratio (RBMC) on Profitability}

The results of the research prove that the RBMC ratio has a positive effect on profitability. This supports the research of Ahmad (2018) which concludes that the RBMC ratio has a positive effect on profitability. This is in line with the research of Ahmad and Prasetyo (2018) and Pratiwi (2017) where the results of the research conclude that there is an influence between the RBMC ratio on profitability.

\section{Indirect Effect of Insurance Premium on Profitability through RBMC Ratio}

In this research it can be proven that insurance premiums have a direct influence on profitability. This proves that the higher the number of premiums owned by the company can directly increase the company's profitability. However, insurance premiums do not have an indirect effect on profitability through the RBMC ratio.

\section{Indirect Effect of Insurance Claim on Profitability through RBMC Ratio}

In this research, there is a direct relationship with a negative direction between the claims variable and the company's profitability. This shows that the risk of claims that arise can reduce the level of company profitability. However, the results of the study show that insurance claims do not have a direct influence on the company's profitability through the RBMC ratio. This is because the calculation of the level of the RBMC ratio that has been required by the government only provides information about the health of the company's financial condition in fulfilling its obligations and managing the risks to be borne.

Richard Alamsyah and Ahmad Lutfi. The effect of insurance premiums, claims, underwriting results, on profitability with a risk-based minimum capital ratio (RBMC) as an intervening variable in general 


\section{Indirect Effect of Underwriting Result on Profitability through RBMC Ratio}

In this research, underwriting results have a positive influence on the level of company profitability. This shows that high underwriting results indicate a good level of risk management that is able to guarantee the level of company profitability, while the underwriting results do not affect profitability indirectly through the RBMC ratio. This is because the calculation of the level of the RBMC ratio that has been required by the government only provides information about the health of the company's financial condition in fulfilling its obligations and managing the risks to be borne.

\section{CONCLUSIONS AND RECOMMENDATIONS}

\section{Conclusions}

Based on the research above, it can be concluded several things including:

1. Insurance premiums have no effect on the RBMC ratio. These results are in line with research conducted by Alamsyah (2017) which concludes that there is no influence between insurance premiums and the RBMC ratio, but it is different from Rahmawati (2017) which states that insurance premiums have an influence on the RBMC ratio.

2. Insurance claims have a negative effect on the RBMC ratio. These results are in accordance with Alamsyah's research (2018) which states that insurance claims have an influence on the RBMC ratio but differ from the research of Tarigan (2015) and Daniel (2017) which concludes that insurance premiums have a positive effect on the RBMC ratio.

3. Underwriting results have a positive effect on the RBMC ratio. These results are in accordance with the research of Tarigan (2015) and Aniseh (2019) which states that underwriting results have a positive influence on the RBMC ratio.

4. Insurance premiums have a positive effect on profitability. These results are in line with the research of Utami and Marwansyah (2017) and Ahmad (2018) which prove that insurance premiums have a positive effect on company profitability.

5. Insurance claims have a negative effect on profitability, this is in accordance with research by Reschiwati (2018) and Pratiwi (2018) which concludes that insurance claims have a negative effect on company profitability.

6. Underwriting results have a positive effect on profitability. this is in line with Ahmad's research (2018) which concludes that underwriting results have a positive effect on profitability, but it is different from Pratiwi's research (2018) which concludes that underwriting results have no effect on company profitability.

7. The RBMC ratio has a positive effect on profitability. These results are in line with Ahmad's research (2018) which concludes that the RBMC ratio has a positive effect on profitability but is different from Rahayu's research (2017) which concludes that the RBMC ratio has no effect on profitability.

8. Insurance premiums are not able to indirectly affect the company's profitability through the RBMC ratio.

9. Insurance claims are not able to indirectly affect the company's profitability through the RBMC ratio.

10. Underwriting results are not able to indirectly affect the company's profitability through the RBMC ratio.

Richard Alamsyah and Ahmad Lutfi. The effect of insurance premiums, claims, underwriting results, on profitability with a risk-based minimum capital ratio (RBMC) as an intervening variable in general insurance companies 


\section{Recommendations}

\section{Managerial}

This research is expected to provide benefits and input for management, especially regarding the factors that affect the level of company profitability. In addition to profitability, the RBMC ratio plays a very important role in terms of measuring the company's health level to ensure its existence, so it is necessary to know what factors affect the RBMC ratio.

\section{Further Research}

Recommendations for further research are expected to complement the limitations of the study by developing the following points:

1. In further research, it is possible to expand the number of samples not only limited to general insurance but also to add the life insurance industry so that it can better describe the actual condition of the population.

2. In further research, it is expected to add other variables that can affect the value of profitability such as reinsurance premium variables, technical reserves or reinsurance commissions.

\section{REFERENCES}

Ahmad, G. N., \& Prasetyo, R. P. (2018). Profitability Analysis of Non-life Insurance: Case in Indonesia Stock Exchange. KnE Social Sciences, 3(8), 335. https://doi.org/10.18502/kss.v3i8.2518

Alamsyah, R., \& Wiratno, A. (2017). Pendapatan Premi, Rasio Hasil Investasi, Laba, Klaim dan Risk Based Capital Perusahaan Asuransi Kerugian di Indonesia. Jurnal Riset $\begin{array}{llll}\text { Akuntansi \& Perpajakan (JRAP), 47-101. } & \text { 4(01), }\end{array}$ https://doi.org/10.35838/jrap.v4i01.152

Aniseh, N., Mardani, R. M., \& Salim, A. (2019). Pengaruh ROA, Resiko Underwriting dan Reasuransi terhadap Solvabilitas Perusahaan Asuransi. E-Jurnal Riset Manajemen, 8(11), 109-119. www.fe.unisma.ac.id

A. P. K. Tarigan, and M. K. Mahfud, 2015. "ANALISIS PENGARUH KEMAMPUAN MEMBAYAR KLAIM, PROFITABILITAS, RISIKO UNDERWRITING, DAN REASURANSI TERHADAP SOLVABILITAS PERUSAHAAN ASURANSI (Studi Pada Perusahaan Asuransi Yang Terdaftar di Bursa Efek Indonesia Periode 2008-2013)," Diponegoro Journal of Management, vol. 0, pp. 584-596,

Arifin, Firman (2013) Pengaruh Rasio Likuiditas, Rasio Retensi Sendiri, Ukuran Perusahaan Dan Tingkat Kecukupan Dana Terhadap Kinerja Keuangan Perusahaan Asuransi Yang Terdaftar Di Bursa Efek Indonesia Periode 2007-2012. Universitas Maritim Raja Haji Ali.

Richard Alamsyah and Ahmad Lutfi. The effect of insurance premiums, claims, underwriting results, on profitability with a risk-based minimum capital ratio (RBMC) as an intervening variable in general insurance companies 
Daniel, Safitri, E., \& Elizabeth, S. M. (2017). Pengaruh Profitabilitas, Ukuran Perusahaan dan Reasuransi terhadap Solvabilitas Perusahaan Asuransi Jiwa Unit Link di Indonesia (Studi Kasus Pada Perusahaan Asuransi Jiwa Unit Link Periode 2012-2016). E-Jurnal Manajemen STIE Multi Data, 8(3), 1-10. https://core.ac.uk/download/pdf/153523779.pdf

Fadlin, Adity (2013) Analisis Pengaruh Risk Based Capital, Penerimaan Premi, Underwriting dan Beban Klaim Terhadap Profitabilitas. Vol 1 No 2

Ghozali, Imam (2011) Aplikasi Analisis Multivariate dengan Program IBM SPSS 19. Edisi 5. Semarang: Badan Penerbit Universitas Diponegoro. Hal: 30-34

Hasanah, Raudhotul Miul (2019) Kinerja keuangan perusahaan asuransi Jiwa Konvensional periode 2015-2018. Jurnal riset manajemen sains Vol 10 No 1 Hal 96-124. doi.org/10.21009/JRMSI.010.1.05

Herman, Darmawi (2016) Manajemen Risiko (Edisi 2), Jakarta: Bumi Aksara, hal. 11

Kasmir, (2014). Analisis Laporan Keuangan. Jakarta : PT Raja Grafindo Persada hal 28-30

Kirmizi, \& Agus, S. S. (2011). Pengaruh Pertumbuhan Modal dan Aset Terhadap Rasio Risk Based Capital (RBC), Pertumbuhan Premi Neto dan Profitabilitas Perusahaan Asuransi. Pekbis Jurnal, 3(1), 391-405.

Leviany, T., \& Sukiati, W. (2017). Pengaruh Risk Based Capital Terhadap Profitabilitas Pada Perusahaan Asuransi Jiwa. Jurnal ASET (Akuntansi Riset), 6(1), 1. https://doi.org/10.17509/jaset.v6i1.8993

Marwansyah, S., \& Utami, A. N. (2017). Analisis Hasil Investasi, Pendapatan Premi, Dan Beban Klaim Terhadap Laba Perusahaan Perasuransian Di Indonesia. JURNAL AKUNTANSI, EKONOMI Dan MANAJEMEN BISNIS, 5(2), 213. https://doi.org/10.30871/jaemb.v5i2.533

Mehr dan Cammack. (2015).,Dasar-Dasar Asuransi, terj. A. Hasyimi, edisi 4 Jakarta: Balai Aksara, Hal 25-27

Mulhadi, (2017). Dasar-dasar Hukum Asuransi,Jakarta : Rajagrafindo. Hal 10 - 14

Peraturan Otoritas Jasa Keuangan (POJK) No 71. (2016). Tentang Kesehatan Keuangan Perusahaan Asuransi dan Perusahaan Reasuransi. 50.

https://www.ojk.go.id/id/kanal/iknb/regulasi/asuransi/peraturanojk/Documents/Pages/PO JK-tentang-Kesehatan-Keuangan-Perusahaan-Asuransi-dan-Perusahaan-

Reasuransi/SAL - POJK Kesehatan Keu PA PR -.pdf

Pratiwi, O. S., \& Azib. (2018). Pengaruh Pendapatan Premi, Beban Klaim, Hasil Underwriting dan Risk Based Capital Terhadap Laba dan Harga Saham (Studi Kasus Pada Perusahaan Asuransi yang Terdaftar di Bursa Efek Indonesia Tahun 2012-2016). Prosiding Manajemen, 4(2), 1260-1266.

Richard Alamsyah and Ahmad Lutfi. The effect of insurance premiums, claims, underwriting results, on profitability with a risk-based minimum capital ratio (RBMC) as an intervening variable in general insurance companies 
The Accounting Journal of BINANIAGA Vol. 06, No. 01, June 2021

p-ISSN: 2527-4309, e-ISSN: 2580-1481

$5^{\text {th }}$ Accreditation Rating: January 14, 2019 - January 13, 2024

Purwadi,Syawal (2017) Pengaruh Kekayaan Yang Diperkenankan dan Risiko Kerugian Yang Timbul Akibat Dari Deviasi Dalam Pengelolaan Aset dan Liabilitas Terhadap Tingkat Solvabilitas. Magister program Akuntansi. Trisakti.

Putu,Sutama (2016) Faktor-faktor yang Mempengaruhi Pertumbuhan Aset dan RBC Perusahaan Asuransi Jiwa Non Syariah di Indonesia.Master Thesis hal 75-81

Rahmawati, Titis. (2017) Analisis Pengaruh Premi , Dana Tabarru, Klaim Dan Likuiditas Terhadap Solvabilitas Dana Perusahaan Asuransi Jiwa Syariah Di Indonesia Tahun 2014-2016. Universitas Islam Indonesia.

Reschiwati. (2018) Random Efect Model: Influence Of Income Premium, Claim Cost, And Underwriting Results On Net Income In Insurance Company In Indonesia. IJMTBR Vol 1 No 1. Hal 1-17. http://www.ijmtbr.com/PDF/IJMTBR-2018-03-09-01.pdf

Sastrodiharjo, I., \& Sutama, I. P. (2016). Faktor-Faktor Yang Mempengaruhi Pertumbuhan Aset Perusahaan Asuransi Jiwa Non Syariah Di Indonesia. Akuntabilitas, 8(1), 18-38. https://doi.org/10.15408/akt.v8i1.2759

Sugiono (2015) Metode Penelitian Kuantitatif, Kualitatif dan R\&D.Jakarta:Alfabeta Hal 13-16

Salim (2018) Asuransi dan Manajemen Risiko. Jakarta :RajaGrafindo Persada. Hal 9 - 12

Surat Edaran Otoritas Jasa Keuangan No. 24/SEOJK.05/2017. https://datapolis.id/database/seojk-nomor-24-seojk-05-2017-pedoman-perhitunganjumlah-modal-minimum-berbasis-risiko-bagi-perusahaan-asuransi-dan-perusahaanreasuransi/

Susilowati, Eny. (2017) Faktor-Faktor Yang Mempengaruhi Solvabilitas Perusahaan Asuransi Umum Di Bursa Efek Indonesia. Institut Pertanian Bogor.

Undang-undang no $40 \quad$ Tahun 2014 tentang Perasuransian https://www.ojk.go.id/Files/201506/1UU402014Perasuransian_1433758676.pdf

Wijaya, R. S. (2014). Faktor-Faktor Yang Mempengaruhi Tingkat Kesehatan Keuangan Industri Asuransi Kerugian di Indonesia. Jurnal KBP, 2(1).

Winarso, Widi.(2014).Analisa Biaya Klaim Nasabah Terhadap Laba Perusahaan Asuransi. Jurnal Moneter. Vol. 1. No 1. https://doi.org/10.31294/moneter.v111.941

Wild, John J., Subramanyam, K. R., dan Halsey, Robert F., (2005), Analisis Laporan Keuangan, edisi 8 Buku 2, Penerjemah: Bachtiar dan Harahap, Jakarta : Salemba Empat, Hal 21-25

Werner R. Murhadi. 2013. Analisis Laporan Keuangan Proyeksi dan Valuasi Saham. Jakarta: Salemba Empat. Hal : 53 - 60

Zen, N. A., \& Manda, G. S. (2021). Pengaruh Premi, Klaim Dan Hasil Investasi Terhadap Laba Pada Perusahaan Asuransi Jiwa Syariah Di Indonesia Tahun 2014-2019. Buletin Studi Ekonomi, 26(1), 1. https://doi.org/10.24843/bse.2021.v26.i01.p01

Richard Alamsyah and Ahmad Lutfi. The effect of insurance premiums, claims, underwriting results, on profitability with a risk-based minimum capital ratio (RBMC) as an intervening variable in general insurance companies 